\title{
A 19-Year-Old Landscape Laborer Dies When Entangled in Auger after Entering the Hopper of a Bark Blower Truck

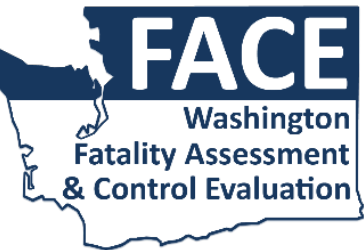

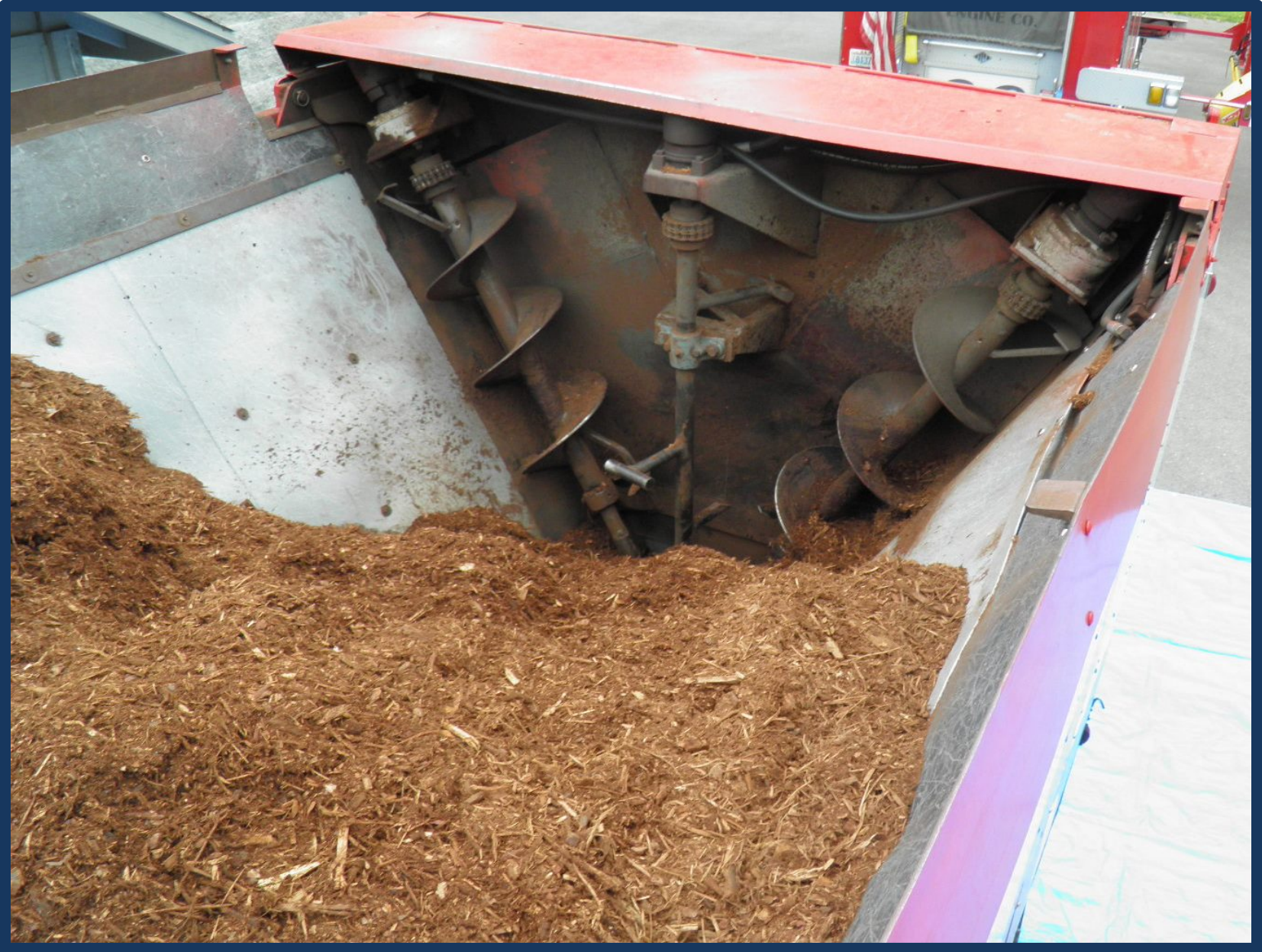

Investigation: \# 15WA02901

Release Date: October 20, 2017

SHARP Report: 52-41-2017

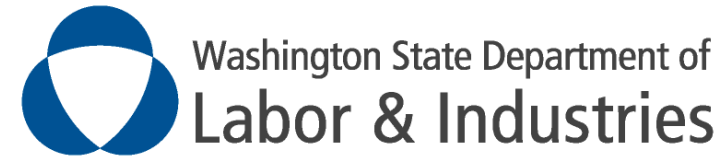




\section{Table of Contents}

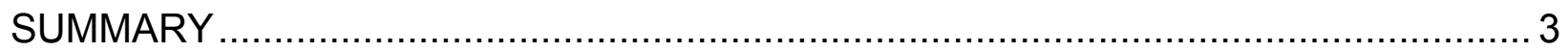

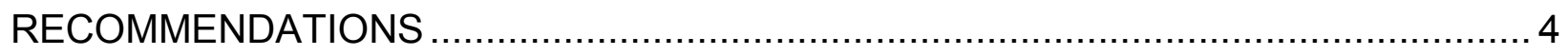

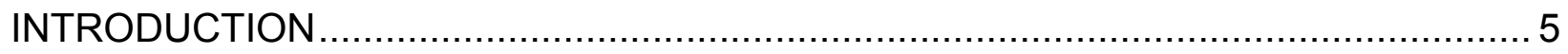

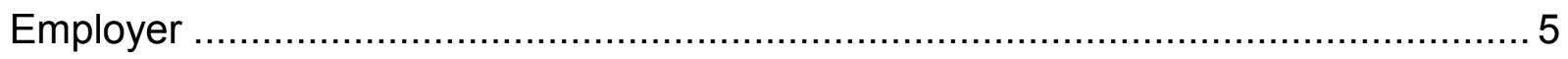

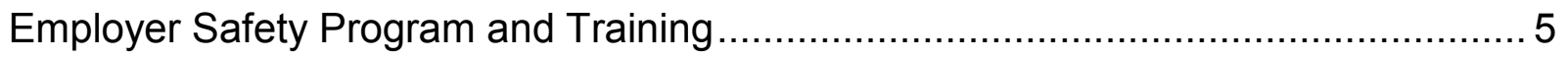

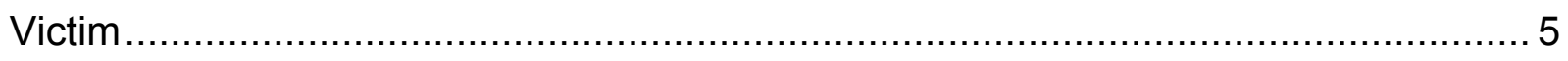

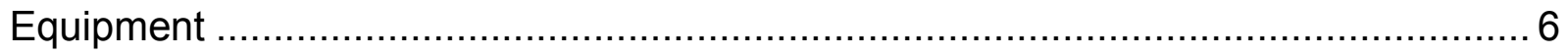

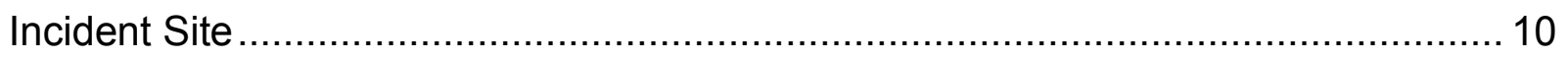

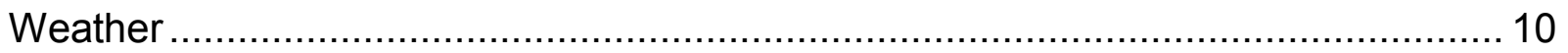

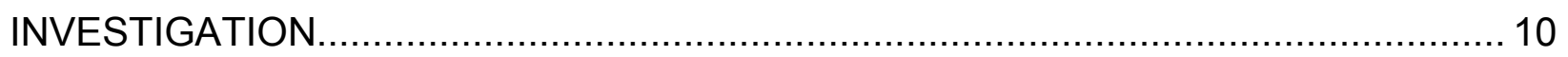

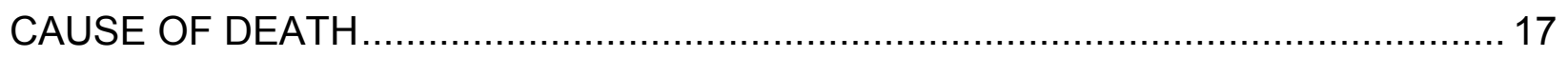

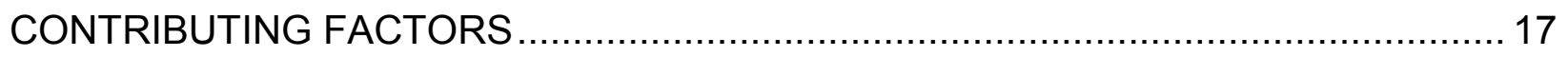

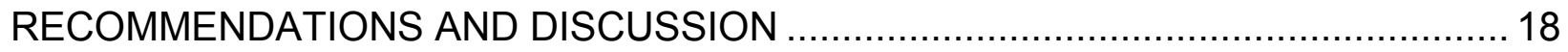

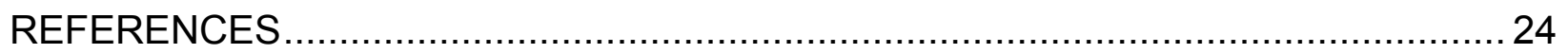

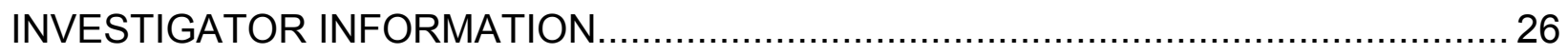

WASHINGTON STATE FACE PROGRAM INFORMATION .................................... 26

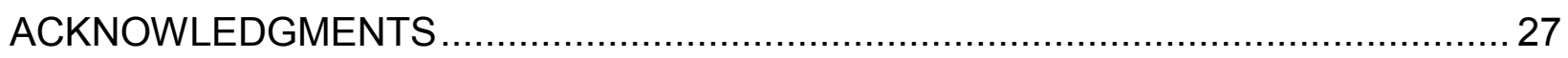




\section{SUMMARY}

In July of 2014, a 19-year-old landscape laborer died after entering the hopper of a bark blower truck and becoming entangled in its rotating auger system. The victim was employed by a company that is a supplier of commercial and residential bark, mulch, and other landscaping materials. The day of the incident was his second day on the job. He had no prior experience in the landscaping industry.

On the day of the incident, the victim, along with a supervisor and another laborer were to deliver a load of bark mulch in a bark blower truck to the yard of a residence. The bark blower truck consisted of a truck-mounted pneumatic blower system powered by a diesel engine. Bulk material was loaded into the hopper and an operator would use a control to engaged the system's power. Located on the hopper floor was a conveyor belt that moved material toward the auger system mounted on the hopper's rear door. This system consisted of a stir rod, to break up the material, and two diagonal augers that would drive the material down into a rotating feeder located on the hopper floor. When the material entered the feeder it would be caught up in the air flow created by the air blower and enter the discharge hose for placement on a site.

The bark blower truck being used that day had broken pressure sensors that would shut down the conveyor belt when the auger system experienced too much pressure from bulk material in the hopper; this would then allow the auger system parts to turn and drive material into the feeder and out the delivery hose. Because of the broken sensors, the hopper's bulk material would bridge over the conveyor belt, forming a tunnel. When tunneling occurred, material would not flow into the feeder and workers were unable to blow the material through the hose onto a site. It had become accepted company practice to have workers inside the hopper standing on bulk material using a pitchfork to move material into the blower system. They would work 1 to 5 feet from the rotating unguarded auger system. This was the case with the victim on the day of the incident.

The supervisor and other laborer could not see the victim working in the truck's hopper as they where blowing bark onto the residence's yard. They heard a clunking noise coming from the truck and bark stopped flowing through the hose. The supervisor used the remote control to shut down power to the system. He then walked over to the truck and called the victim's name. When he received no answer, he instructed the laborer to call 911. Police and fire department emergency medical service responders arrived within minutes. A police officer looked into the hopper and found the deceased victim entangled in the stir rod of the auger system. 


\section{RECOMMENDATIONS}

To prevent similar occurrences in the future, Washington State Fatality Assessment and Control Evaluation (FACE) investigators concluded that to protect employees from the hazard of being caught in blower truck augers employers should follow these guidelines:

- Conduct a job hazard assessment (JHA) of machinery, processes, and tasks to identify potential hazards to which workers might be exposed.

- Develop, implement, and enforce:

- A written accident prevention program (APP) that is effective in practice and that includes training on identified hazards, hazard recognition, and the avoidance of unsafe work conditions and practices specific to the worksite.

- Written standard operating procedures (SOPs) that are specific to bark blower truck operations. Train and supervise employees in these procedures.

- A comprehensive written hazardous energy control program including a lockout/tagout (LOTO) procedure and training for maintenance and servicing of bark blower trucks.

- A comprehensive written program detailing procedures for safe entry into or work in permit-required confined spaces, such as bark blower truck hoppers.

- Maintain machinery and equipment in safe operating condition. Remove malfunctioning machinery and equipment from service and repair or replace.

- Affix labels to equipment containing graphics providing hazard warnings and instructions for the safe use of equipment.

- Ensure that young workers and inexperienced workers are adequately trained and supervised to perform their work safely. 


\section{INTRODUCTION}

In July of 2014, the Washington FACE Program was notified by the Washington State Department of Labor and Industries (L\&I) Division of Occupational Safety and Health (DOSH) of the death of a 19-year-old landscape laborer who became entangled in a rotating auger system inside the hopper of a bark blower truck.

Washington State FACE investigators reviewed documents which included the victim's death certificate, police report, medical examiner's report, and the DOSH investigation file.

\section{Employer}

The employer is one of the largest suppliers of commercial and residential topsoil, bark, mulch, aggregate rock, and other landscaping materials in western Washington. They have been in business for 36 years. The company has one office and nine business locations in western Washington. At these sites, the company uses a variety of equipment to process and deliver landscaping products. About 20 years prior to the incident they started delivering their products using trucks fitted with blower systems. One of the services that they provide is delivery and spreading of bark, mulch, compost, wood chips, and lightweight soil by blower trucks. Approximately 200 workers are employed during the summer.

\section{Employer Safety Program and Training}

The employer had a written accident prevention program (APP), a lockout/tagout (LOTO) program, and confined space program, but it did not address bark blower truck operations and associated hazards. Employees working on the bark blower trucks were not trained on LOTO or confined space entry. Bark blower trucks were not included in the employer's written confined space program, and their hoppers were not treated as permit-required confined spaces by managers, supervisors, or employees. Employee training was through verbal instruction provided by a supervisor at the job site. A DOSH inspection determined that employees did not have knowledge of safe operating procedures relating to LOTO and confined space entry.

\section{Victim}

The 19-year-old victim was hired by his employer to work as a laborer. The day of the incident was his second day on the job. His employer had not provided him with any formal training. He had received informal verbal instruction from a supervisor on his first work day. He was attending a community college and this was a summer job.

Previously, he had worked at a hardware store. This was his first job in the landscaping industry. 


\section{Equipment}

The piece of equipment involved in the incident was a truck-mounted pneumatic blower system that was used to deliver bark, mulch, and other landscaping materials to residential and commercial customer sites (photo 1). The truck and blower system are together referred to by manufacturers and landscape industry users as blower trucks or bark blower trucks. The blower system was mounted on the chassis of a Freightliner truck. The bark blower truck was manufactured by Express Blower (model TM-20) in 1998 and bought used by the employer in 2007 . The truck was the oldest of eight bark blower trucks of different models by the same manufacturer in the employer's fleet. All of the employer's trucks had essentially the same mechanical operation, with the main difference being the internal configuration of the the hopper.

The truck's open top cargo hopper is approximately 20 feet long and 6 feet high, and holds approximately 20 cubic yards of bulk material (photo 2 ). It has walls that slope inward at a 60-degree angle toward the bottom. The top of the hopper is approximately 8 feet wide and narrows to approximately 2 feet at the bottom.

A conveyor belt mounted on the frame of the truck is located on the bottom of the hopper and runs intermittently to carry material toward the rear of the hopper where two diagonally positioned augers (screw conveyors) and a vertically positioned stir rod (mixer or stirrer) are situated in close proximity to each other (photo 3 and figure 1). Hydraulic motors drive the augers and stir rod. The augers and stir rod, located on the hopper's rear door, rotate to drive bark down into a rotating feeder mechanism at the end of the conveyor. The augers and stir rod rotate in a circle around 4-foot shafts. The blades on the augers extend out from the shaft approximately 8 inches. The stir rod has 4 projections extending outward 6 to 12 inches from the shaft, and rotates at a higher rate of speed than the augers. The purpose of the stir rod is to break up the bark. The feeder, which has rotating blades to cut up the bark, collects the material where it becomes caught up in an air flow created by the air blower and is transported through a discharge hose for placement on a site.

The self-contained blower system operates using its own diesel engine. According to the manufacturer's operation and safety manual, turning off the engine shuts down all power to the all the blower system's hydraulically controlled operations (photo 13). Removing the key from the ignition creates a positive lockout of the Power Take Off (PTO) and hydraulic systems. The blower system can be operated by controls located on the side of the truck and by a remote control.

Access to the inside of the hopper is gained by climbing a ladder mounted on the hopper's rear exterior (photo 4). As there is no ladder on the hopper interior, employees would climb down the stationary augers (photo 3 ). The hopper was not intended for 
human occupancy during the delivery of landscaping materials due to its design and the presence of unguarded augers, stir rod, and feeder mechanism.

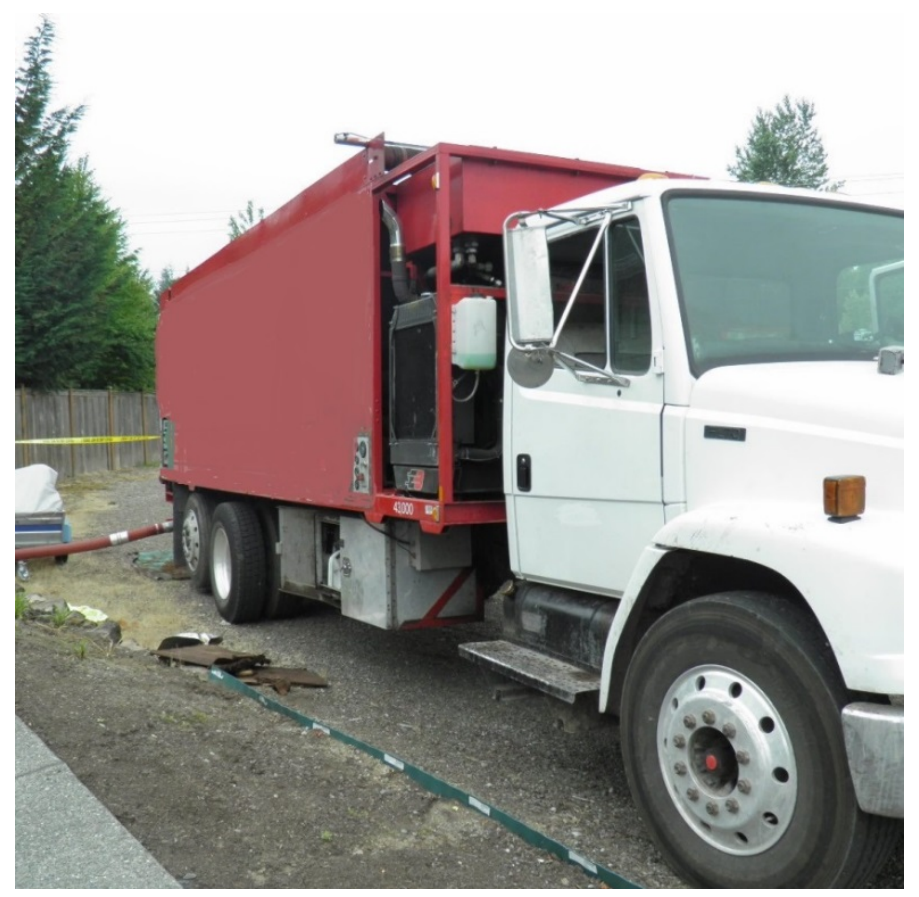

Photo 1: Bark blower truck at the incident site. The victim was working inside the cargo hopper near the rear of the truck. The delivery hose can be seen extending from the rear of the truck.

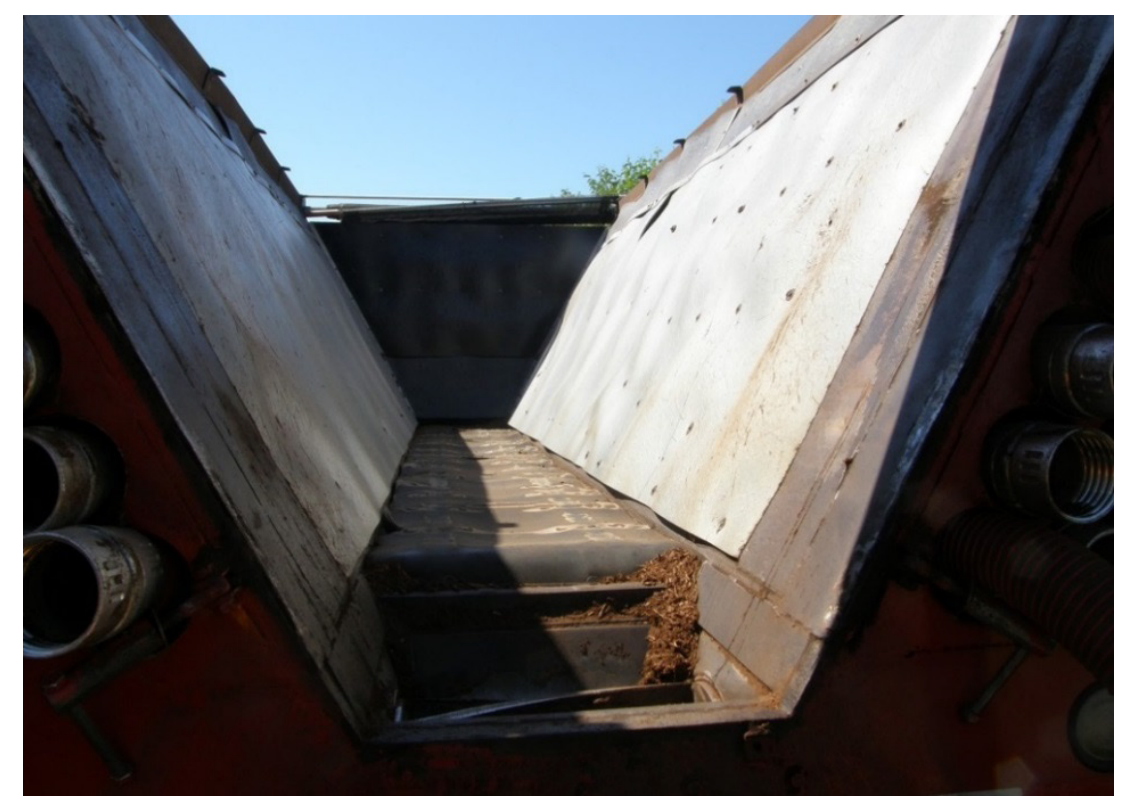

Photo 2: The empty cargo hopper of the bark blower truck. The material conveyor belt and feeder mechanism can be seen on the hopper bed. 


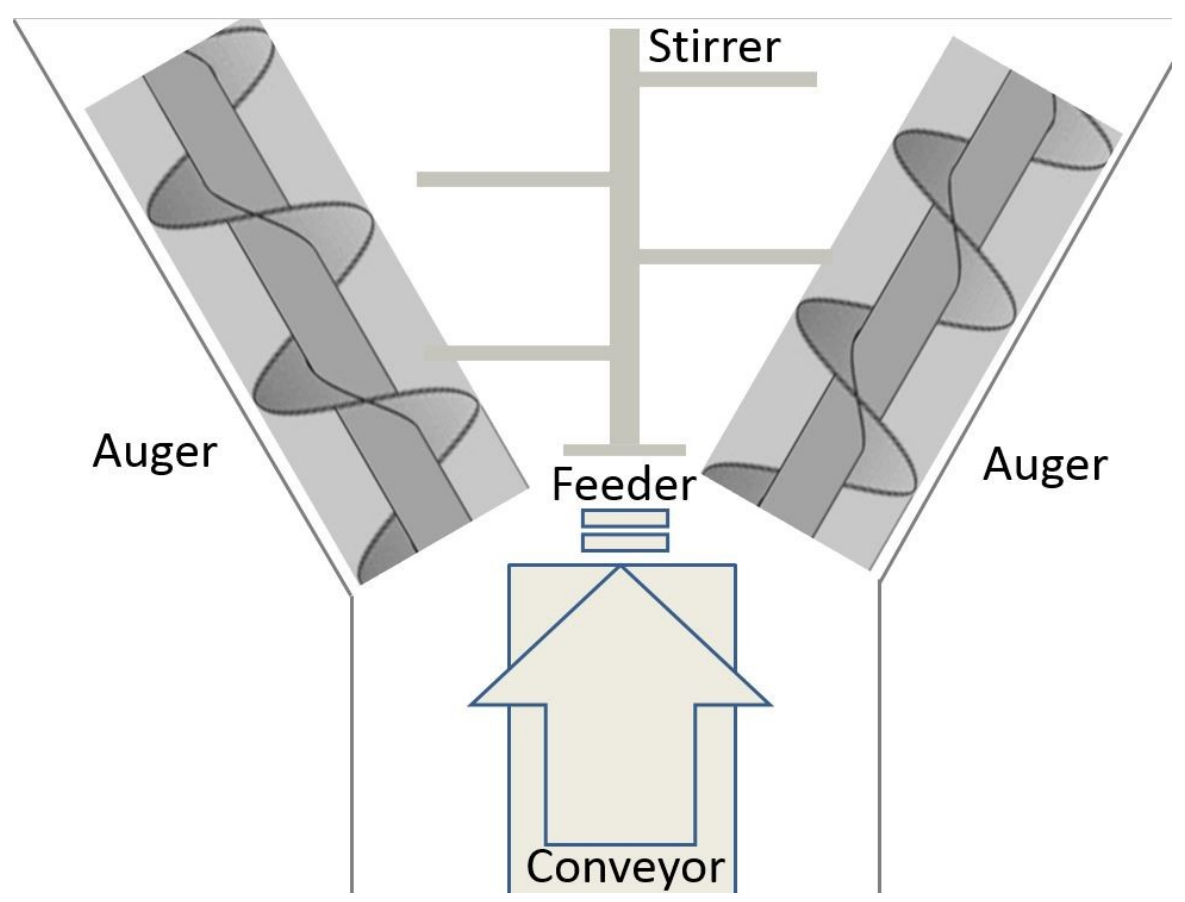

Figure 1: Illustration of how bulk material is delivered into the feeder mechanism on the cargo hopper bed.

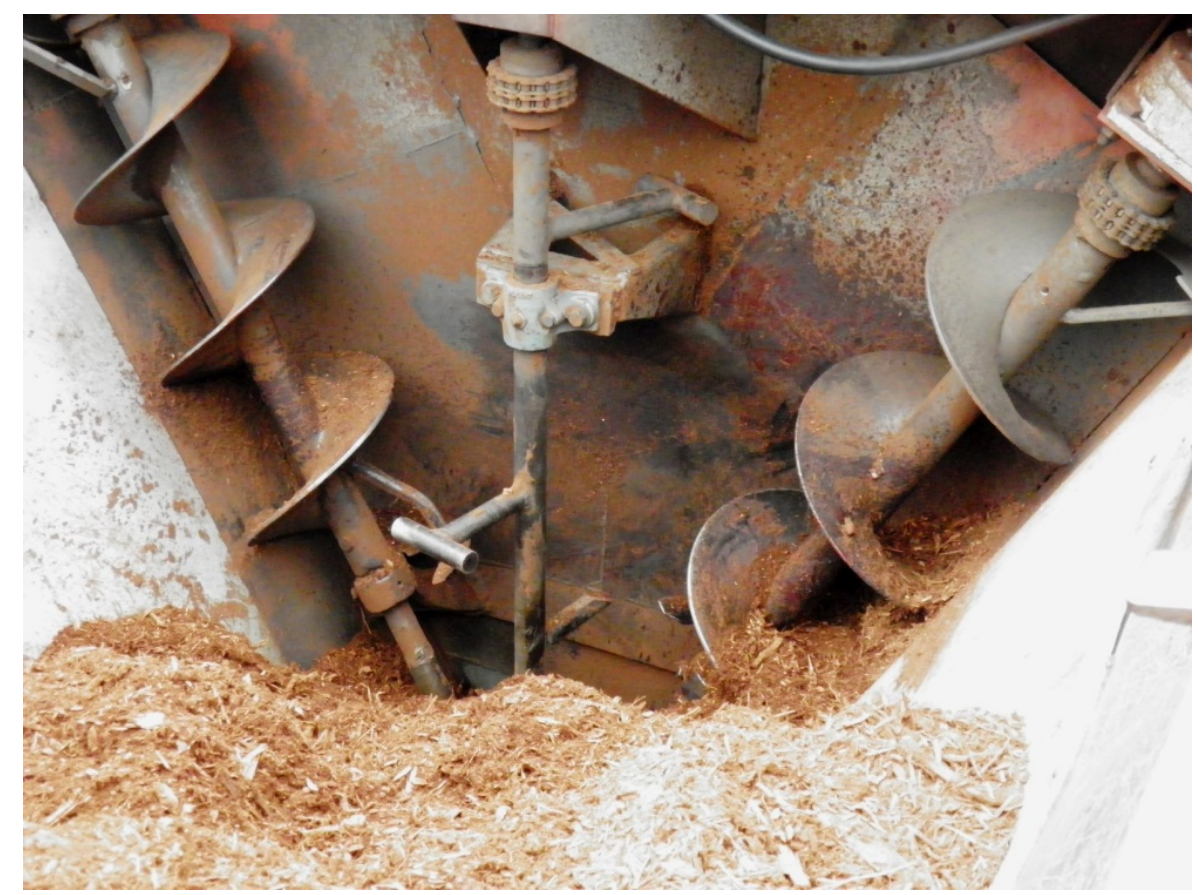

Photo 3: The auger system consisting of two augers and a stir rod used to deliver bulk material into the feeder mechanism located on the cargo hopper bed. The auger system is located on the rear interior of the bark blower truck. 


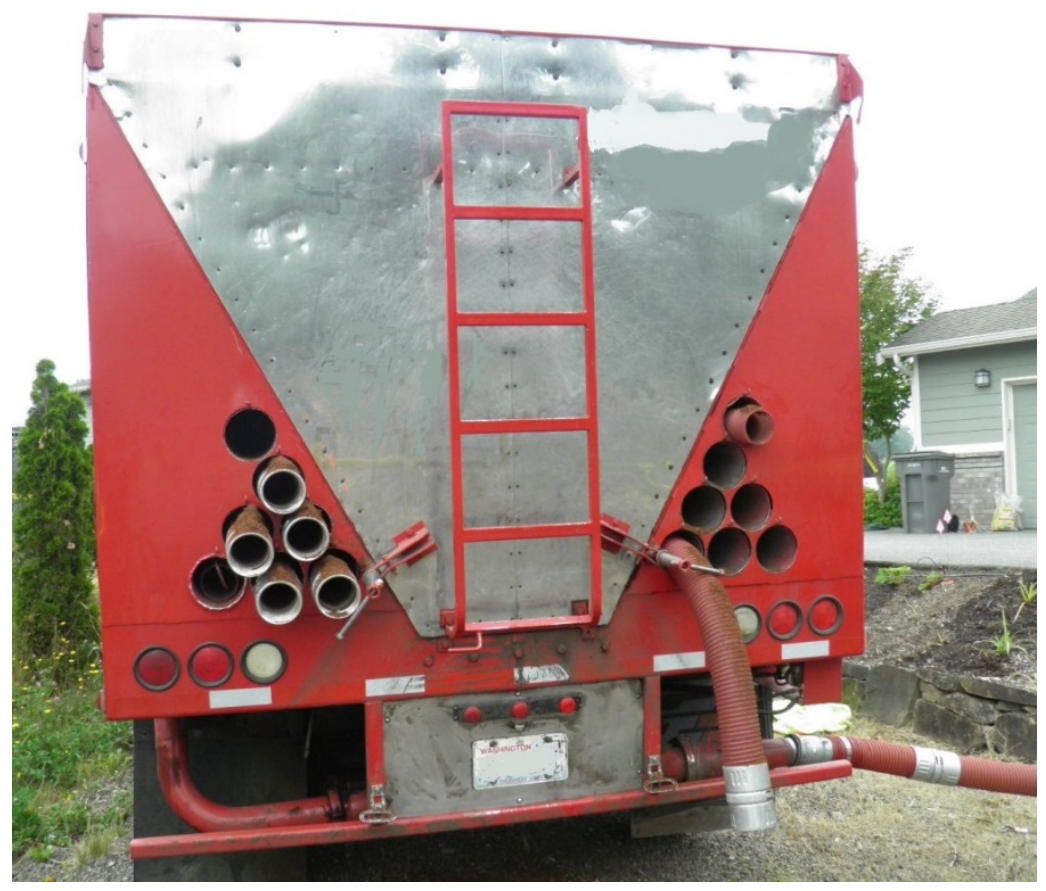

Photo 4: Rear of the bark blower truck with the hopper access ladder and hose assemblies.

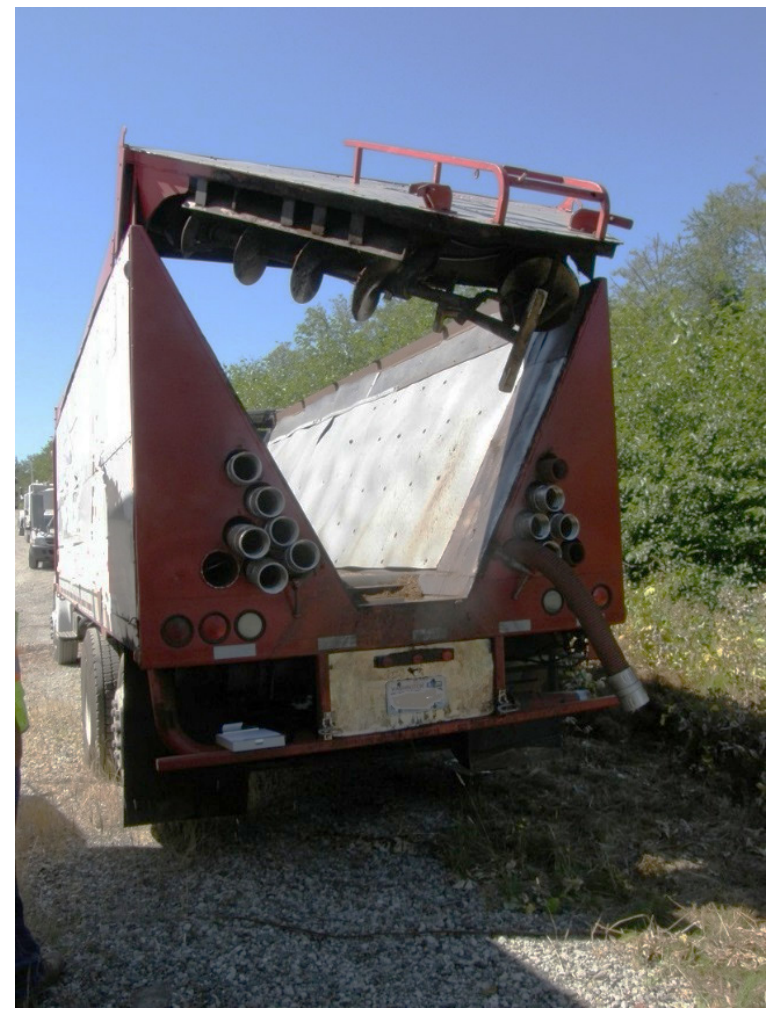

Photo 5: Rear of the bark blower truck in the open position showing the cargo hold and the auger system. 


\section{Incident Site}

The incident took place at a residential site where bark was being delivered to a customer's yard.

\section{Weather}

At the time of the incident, the weather was overcast and 60 degrees with a $5 \mathrm{mph}$ breeze.

\section{INVESTIGATION}

On the day of the incident, the bark blower truck was loaded with bark mulch at a yard operated by the employer. At 7:15 a.m. the crew of three employees tarped the loaded truck and then traveled to a customer site where they were to spread bark mulch on a residential property. The crew consisted of the blower truck driver, who acted as the crew leader or supervisor, and two laborers, one of whom was the victim. All of the employees were relatively new to the job. The crew leader had worked for the company for four months, one laborer had been an employee for about a month, and for the second laborer, the victim, it was his second day on the job. The victim had received verbal instruction from a supervisor on his first day of work. None of the three had attended a company safety meeting.

After arriving at the delivery site at 8:05 a.m., the customer walked the crew around the property showing them where to apply the bark. The crew leader then assigned the victim to work inside the bark blower truck hopper, where he had worked on his first day at another job site. The other laborer was to hold and help move the delivery hose to spread the bark. The crew leader would operate the blower through a remote control and guide the hose to spread the bark. The crew then ran out the delivery hoses. Shortly after they went about using the hoses to spread the bark, the blower stopped shooting bark through the hose.

Bulk material would often bridge over the moving conveyor belt, causing a tunnel or void to form that would prevent the material from reaching the auger system and feeder. This would cause a stoppage of the flow of material into the delivery hose. DOSH investigators identified broken hydraulic pressure sensors in the blower system, a maintenance-related issue, as a cause of the tunnelling. These pressure sensors would automatically shut off the conveyor belt when the auger system experienced too much pressure from bulk material in the hopper (photo 14). This would happen when there was too much bark near the feeder. When the pressure was relieved on the augers and stir rod, then they were able to turn and drive the bark down into the feeder mechanism. When the pressure on the augers was lessened, the sensors would then restart the movement of the conveyor. Due to the age of the bark blower, the company service 
department manager stated that they were unable to find replacement parts for the broken sensors. Company service department records contained recommendations by service mechanics that this blower truck be taken out of service because of the broken sensors.

DOSH investigators suspected a possible further contributing factor to the tunneling of bulk material in the hopper due to its $\mathrm{V}$-shaped configuration, which may have caused too much friction between the bark and the hopper walls that resulted in tunneling. Also, the narrowness of the conveyor belt may have been contributory. According to DOSH investigators, the company's manager of bark blower operations stated that this problem occurred frequently in this older model incident bark blower truck. It happened less frequently in other employer owned models, though it would occasionally occur in those newer models as well. Investigators were not able to determine whether any of these design factors contributed to the tunneling. Manufacturers of bark blower trucks have noted that the design and operational components of the hopper and the blower feed system may factor into whether bulk material bridges and forms tunnels inside the hopper.

When tunneling occured, the employer had an unwritten procedure for resolving the stoppage. This procedure involved shutting down the blower system, an employee would enter the interior of the hopper by climbing up the access ladder on the rear of the truck. When the employee was in the hopper, the blower system would be restarted and the employee would stand on the top of the bulk material and use a pitchfork to break up the material to get it to moving toward the rear of the hopper where the auger system and feeder is located. When using this bark blower truck, employees felt that it was necessary to have a worker performing this task almost continuously. Typically, employees would spend between 30 minutes and $1 \frac{1}{2}$ hours per delivery working in the hopper using a pitchfork to manually feed the blower system with material. As they did this, they sometimes would get within 1 to 5 feet of the rotating augers and stir rod. Occassionally pitchforks would be drawn into the auger system. Company management and supervisors were aware of this practice and accepted it as the standard operating procedure for this truck. This was not a task that employees wanted to do, so generally new employees were the ones assigned to do it. The operator's manual for the truck indicated that no one should enter the truck's cargo hopper without performing lockout/tagout of the blower system's engine.

On this morning when the bark stopped flowing from the hose, the crew leader shut down the blower system and then all three employees entered the hopper to free the bark so that it would flow freely into the feeder. After performing this task, they went back to spreading bark. After a short while, again the bark stopped flowing. They then opened the back of the truck and cleaned the augers and feeder. The crew leader and the other laborer returned to working in the back yard on the other side of the 
customer's house from the bark blower truck. The victim remained in the hopper with a pitchfork to ensure that the bark continued to flow into the feeder. Neither the crew leader nor laborer could see or hear the victim.

The crew leader engaged the blower system by means of a remote control and he and the laborer resumed blowing bark onto the yard. Approximately 5 minutes later at 8:56 a.m. the crew leader and the laborer heard a clunking noise coming from the truck and bark stopped flowing through the hose. The crew leader used the remote control (photo 11) to shut down the system and he and the laborer walked back to the truck to check the hose for blockage. Approaching the truck, they called out for the victim, but received no answer. Upon reaching the truck, the crew leader struck the side of the truck and again called the victim's name. Still there was no response. Alarmed that something had happened to the victim, he instructed the laborer to call 911 . He then called his supervisor.

Within minutes, police and fire department emergency medical service responders arrived. A police officer looked inside the truck's hopper and found the deceased victim entangled in the stir rod of the auger system.

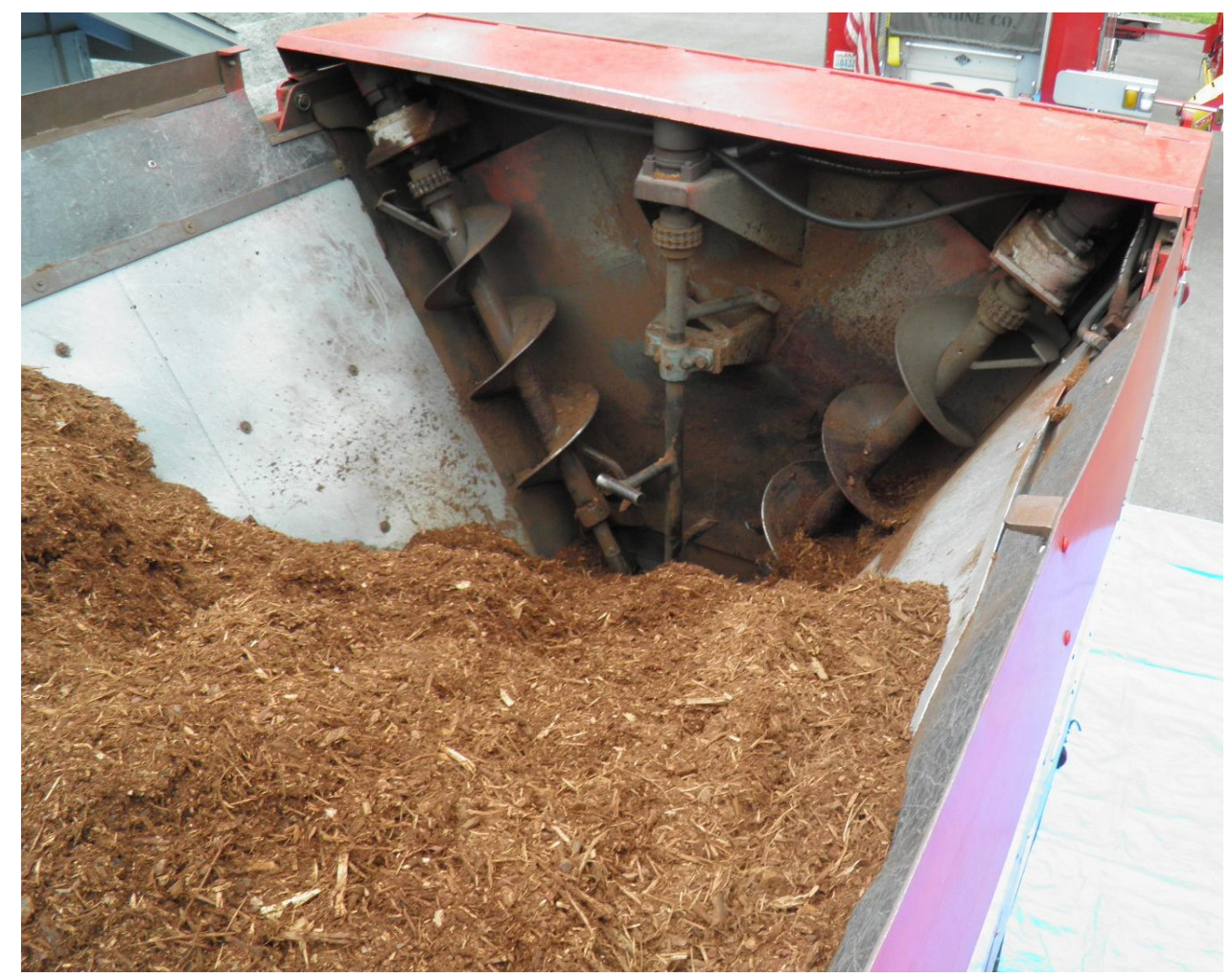

Photo 6: Inside of bark blower truck hopper at the incident scene. The victim had been standing on the bark material using a pitch fork to feed bark into the blower feeder when he became entangled in the stir rod of the auger system. 


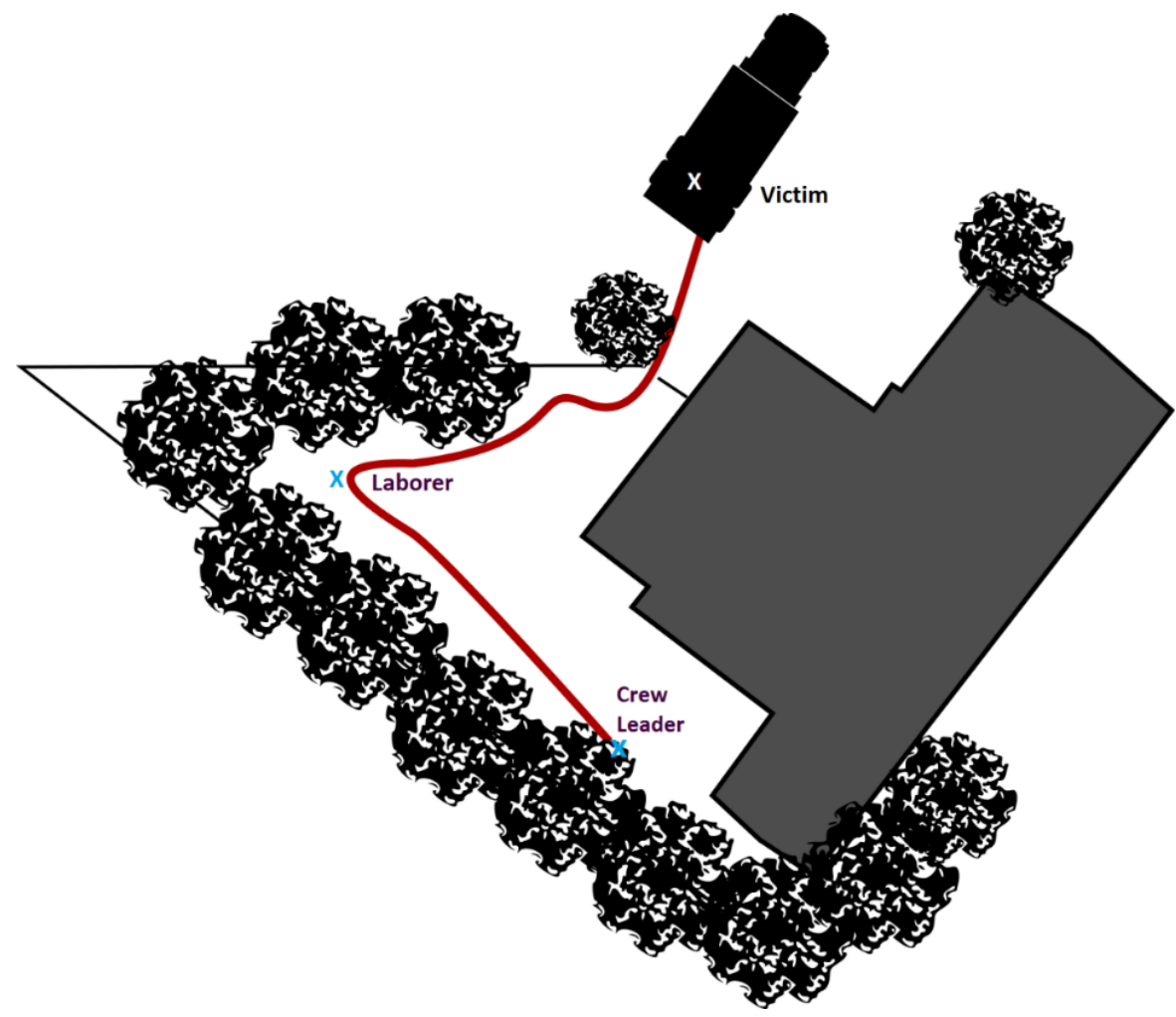

Figure 2: Incident scene schematic showing approximate locations of blower truck and three employees at the residential delivery site [figure not to scale].

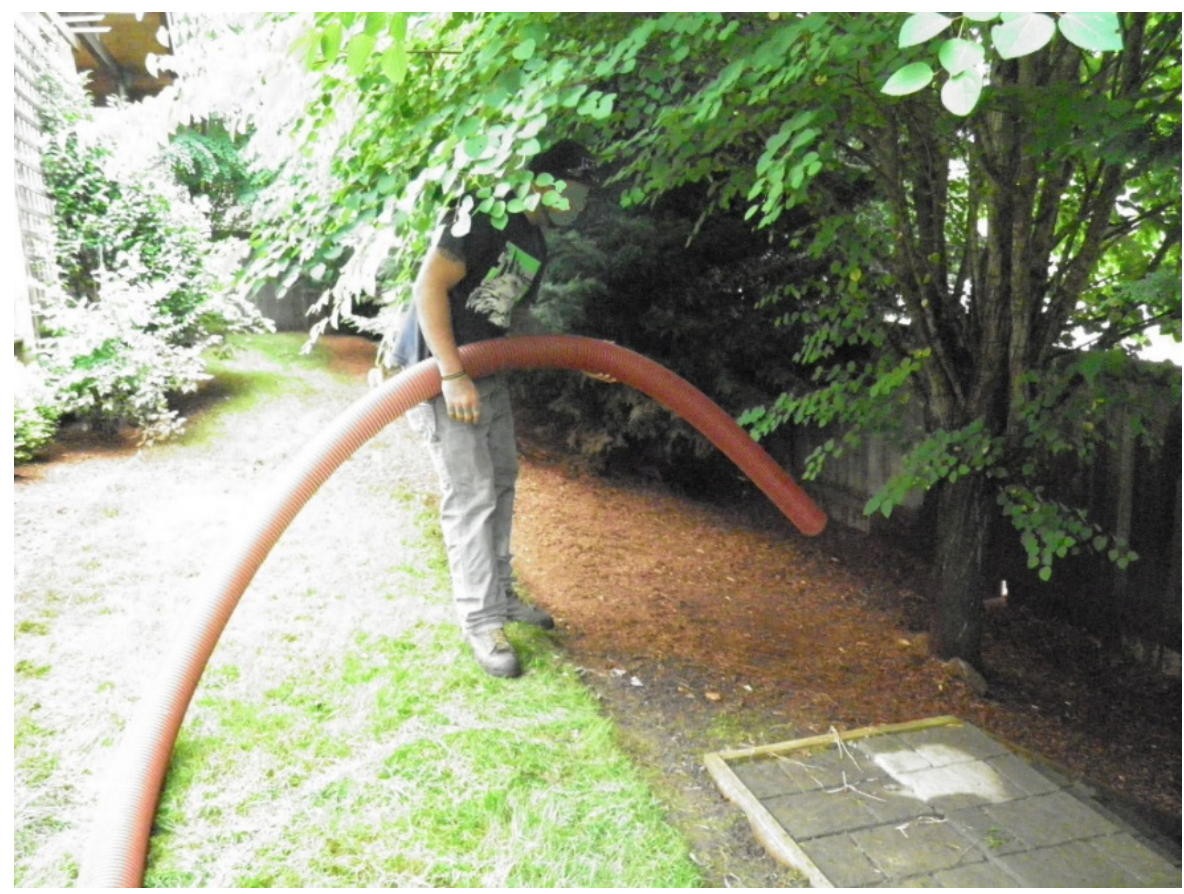

Photo 7: Approximate location of the crew leader with the blower delivery hose at the residential incident site. 


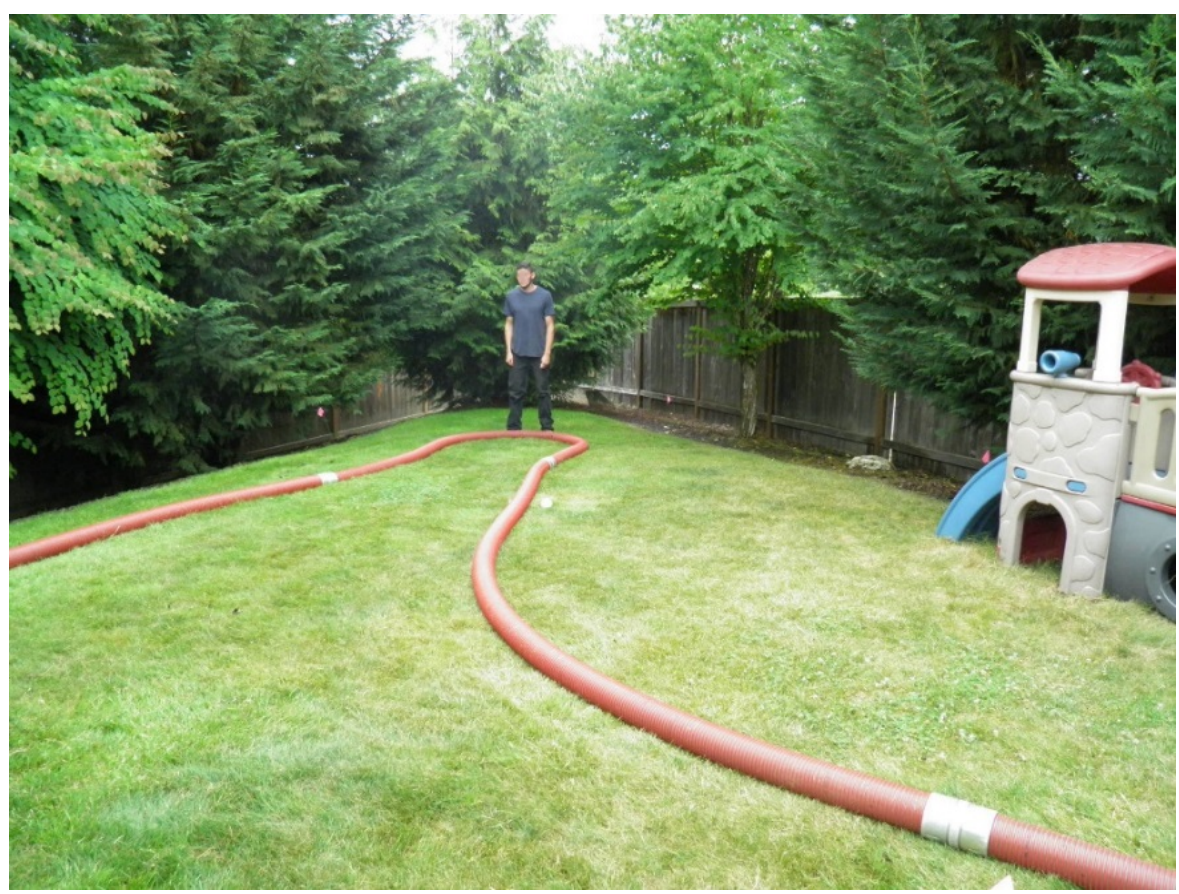

Photo 8: Approximate location of the laborer whose task was to move the delivery hose as the bark was being applied to the yard.

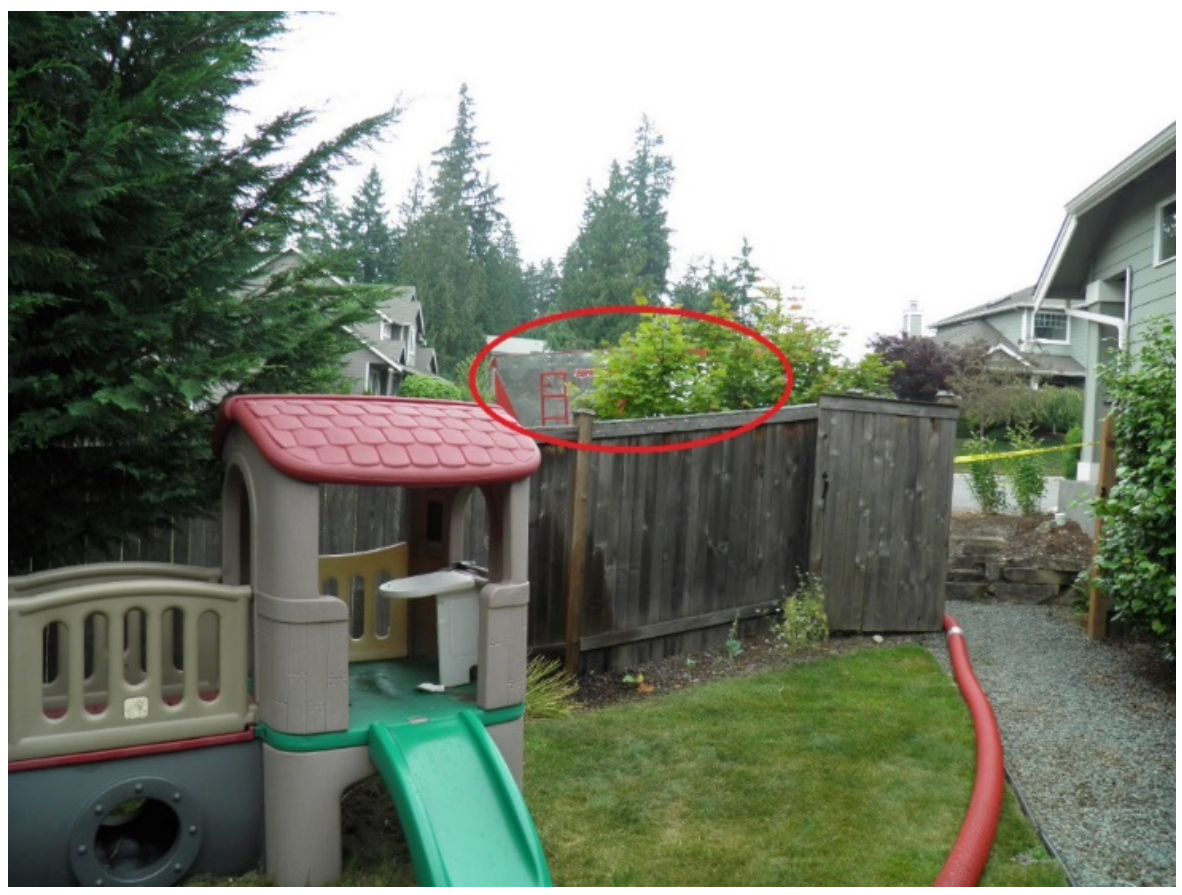

Photo 9: Residential yard where two employees were spreading bark while the victim was working in the hopper. The red circle indicates the blower truck's location. 


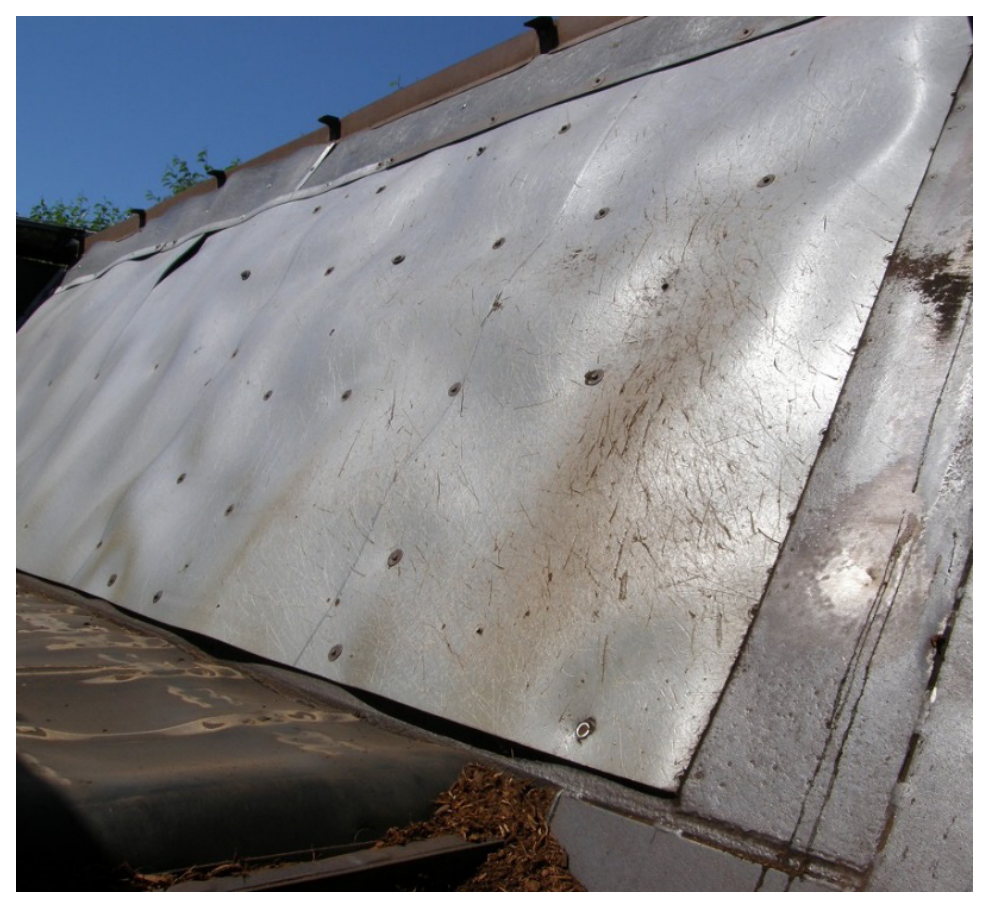

Photo 10: Interior wall of the bark blower truck's hopper. Scratches on the rear of the wall near the auger system may have resulted from pitch forks used by employees to feed bark into the blower system while standing on the bark.

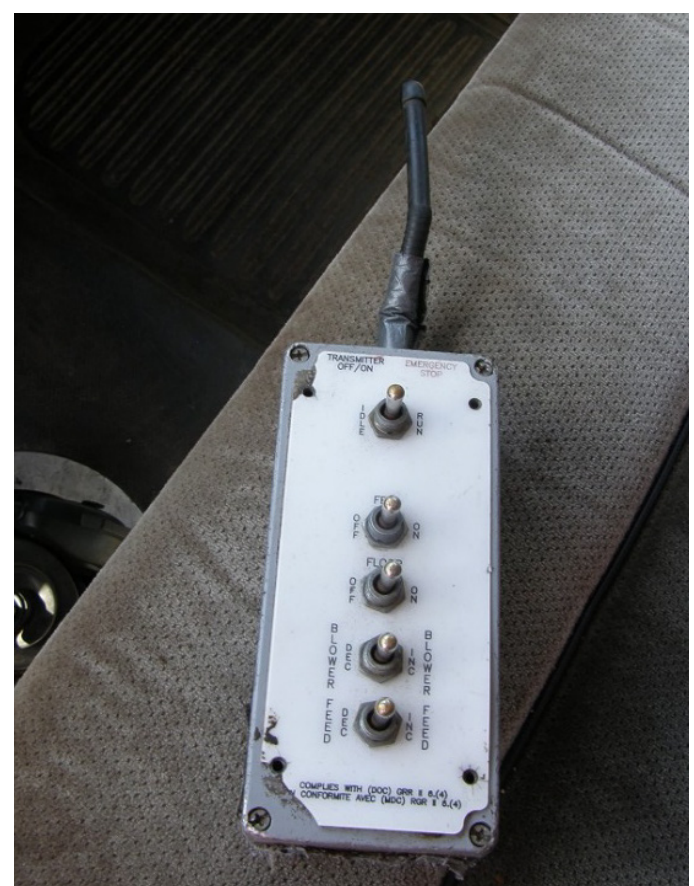

Photo 11: Remote control used by the crew leader to operate the blower system.

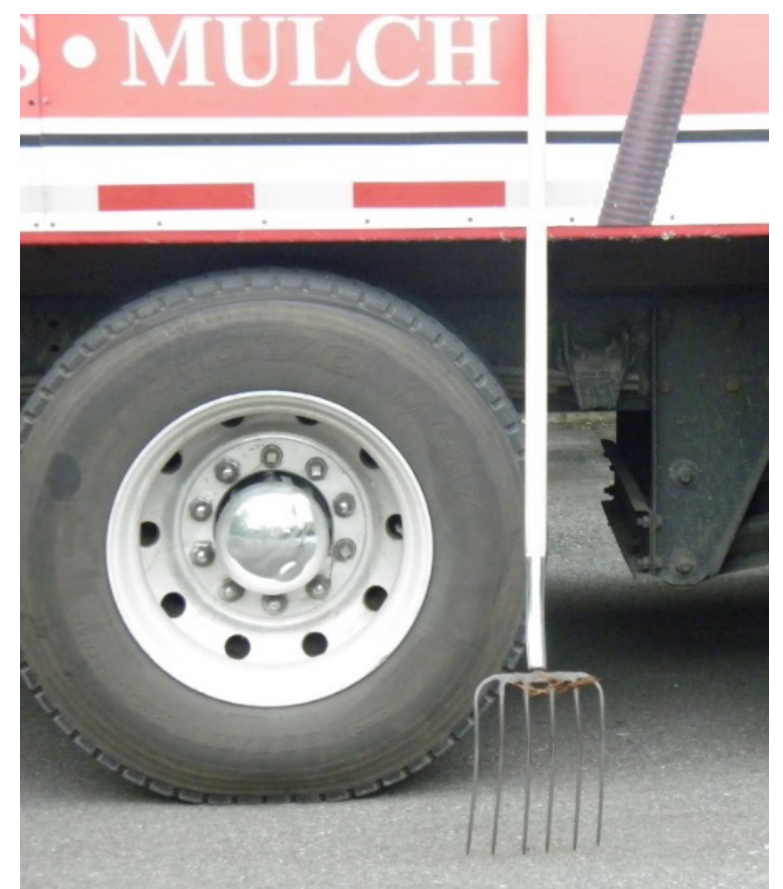

Photo 12: Pitchfork that the victim was using to move bark into the feeder. 


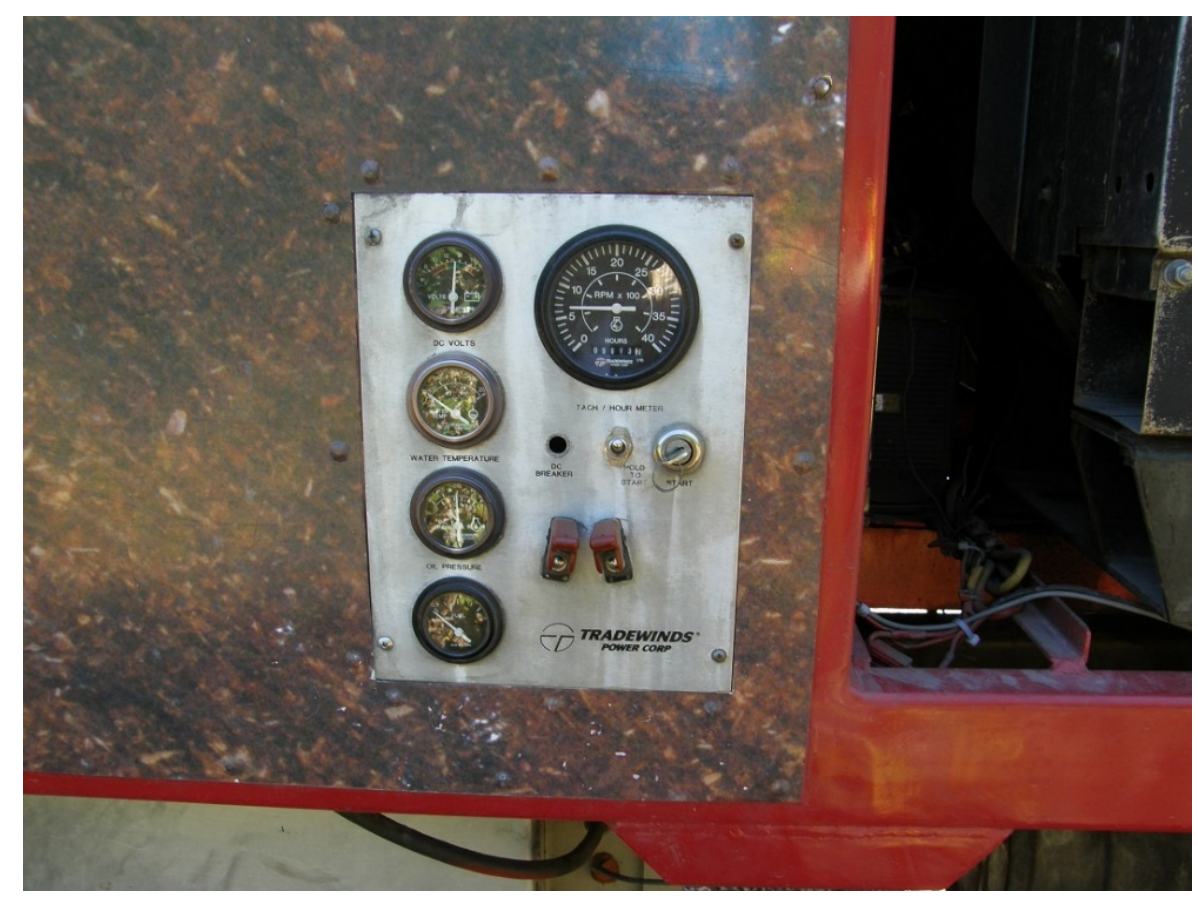

Photo 13: Engine controls for the blower system. The engine's power is controled by using a key.

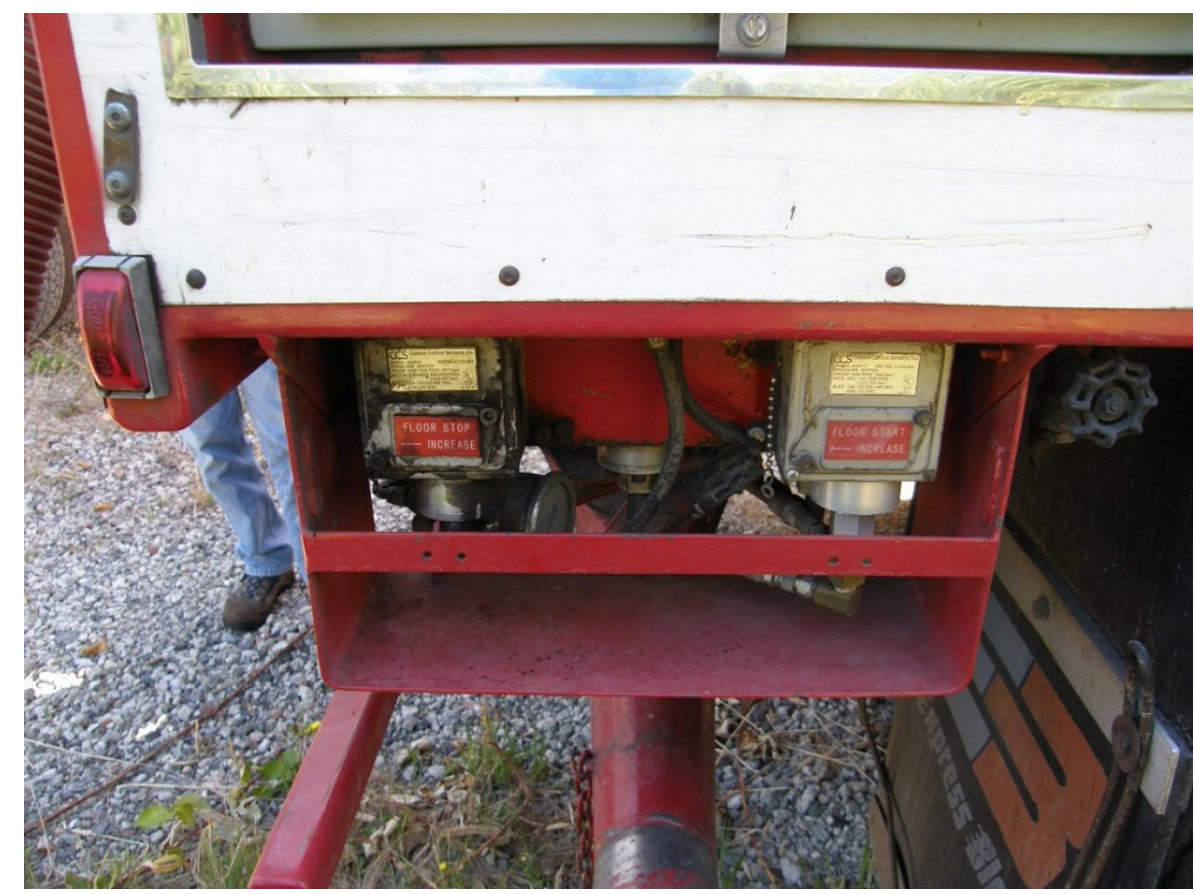

Photo 14: Pressure control switches on bark blower truck that were not operative and for which employer could not find replacements. 


\section{CAUSE OF DEATH}

According to the death certificate, the medical examiner reported the cause of death as "blunt force injuries of the head, trunk, and extremities."

\section{CONTRIBUTING FACTORS}

Occupational injuries and fatalities are often the result of one or more contributing factors or key events in a larger sequence of events that ultimately result in the injury or fatality. Washington FACE investigators identified the following factors that may have contributed to the death of the laborer:

- Employer's accident prevention program (APP) did not address bark blower truck operations and associated hazards, nor did it contain adequate instruction for employees.

- A safety and health training program providing adequate instruction for employees working on or around bark blower trucks was not developed and enforced.

- Permit-required confined spaces were not identified.

- Procedures for entering the permit-required space of the hoppers of bark blower trucks were not developed.

- Employees were not prevented from entering the hoppers of bark blower trucks while unguarded mechanical equipment was operating.

- New and inexperienced employees were not properly trained and supervised to avoid hazards.

- Lockout/tagout procedures were not used to control the blower system when employees were working in the bark blower hopper.

- Employees were not trained in lockout/tag out procedures.

- Blower system manufacturer's operating procedures were not followed.

- Maintenance of the blower system was not addressed. 


\section{RECOMMENDATIONS AND DISCUSSION}

\section{Recommendation 1: Conduct a job hazard assessment (JHA) of machinery, processes, and tasks to identify potential hazards to which workers might be exposed.}

Discussion: Employers should conduct a JHA of machinery, processes, and tasks to identify any potential hazards to which their workers might be exposed to during operation. This JHA should occur when new machinery or equipment is acquired, annually, and when safety concerns arise. When hazards are identified then they must then be properly controlled. JHA results should be used as the basis for an accident prevention program (APP).

Employees routinely entered the blower truck's hopper and used a pitchfork or shovel to unjam material due to the tunneling caused by the moving conveyor on the hopper's bed that would not allow the material to enter the feeder mechanism. While doing this, employees were standing on top of bark or other material one to five feet from the two rotating augers and stir rod and the rotating parts of the feeder mechanism. The augers and stir rod rotate at speeds and forces that would prevent a person from escaping once entanglement occurred.

In this case, a JHA could have identified the hazards of being caught up and entangled in the auger system or feeder mechanism. Procedures then could have been created to control employee exposure to these hazards by allowing only qualified personnel to enter the hopper, and then only after proper lockout/tagout (LOTO) procedures had been followed.

Recommendation 2: Develop, implement, and enforce a written accident prevention program (APP) that is effective in practice and that includes training on identified hazards, hazard recognition, and the avoidance of unsafe work conditions and practices specific to the worksite.

Discussion: In this case, the employer's written APP did not address the hazard of entering the bark blower truck hopper to resolve stoppages due to tunneling of material. Employers should use tools like a JHA to evaluate machinery, processes, and tasks performed by workers to identify and assess potential hazards and then use the results from the JHA to develop, supervise, implement and enforce a safety program.

All Washington State employers are required to have a formal, written APP. (See www.Ini.wa.gov/safety/topics/atoz/APP/) The APP must tailored to the particular needs of the employer's workplace and requires employers to, among other things, identify workplace hazards that could harm employees and then reduce or eliminate these hazards. 
Additionally, as part of their APP employers must provide a detailed safety orientation to employees so that they understand the possible hazards of their job and how to work safely. Employee training should include on-the-job instruction prior to their job assignment.

(Some states, other than Washington, have their own worker safety program initiatives or guidelines that are either mandatory or voluntary, depending on the state. Other states' workplaces fall under Federal OSHA jurisdiction where there is currently a proposed Injury and IIIness Prevention Program (IIPP) standard.

See www.osha.gov/dsg/InjurylllnessPreventionProgramsWhitePaper.html

Recommendation 3: Develop, implement, and enforce written standard operating procedures (SOPs) that are specific to bark blower truck operations. Train and supervise employees in these procedures.

Discussion: There was an unwritten company procedure that while operating the incident bark blower truck that an employee would work inside the hopper to ensure that material would flow properly into the feeder mechanism. The expectation by management was that an employee would stand on bulk material inside the hopper, about 8 to 10 feet, from the rotating auger system and use a pitchfork or shovel to move material into the feeder. This procedure was used in the operation of other company owned trucks as well, though it was not required as often.

Employers should train employees on SOPs and ensure supervision to prevent them from entering the cargo hoppers of bark blower trucks while the equipment is operating.

The bark blower truck's hopper had an auger system consisting of two angled rotating augers and a stir rod. These were unguarded, as the manufacturer did not intend for workers to be inside the hopper when the auger system was active. The victim became entangled in the stir rod of the auger system and crushed between the hopper wall and one of the augers.

Employers should develop SOPs to prevent workers from coming in close proximity to unguarded components of operating equipment that have entanglement points, such as the auger systems of bark blower trucks.

The employer did not have a copy of the manufacturer's operator manual for the blower truck at the time of the incident. After the incident a copy of the operator's manual was obtained by the employer. The manual stated that LOTO of the truck's energy system must be performed before personnel enter the cargo hopper. It indicated that LOTO was required to prevent the startup of mechanical equipment inside the hopper, which included all components of the blower system including the augers (screw conveyors), 
stir rod, feeder, and conveyor belt floor. Removing the key from the blower system engine's ignition creates a positive lockout of the Power Take Off (PTO) and the blower system's hydraulically controlled operations.

To ensure the safety of workers, employers should develop SOPs that strictly follow equipment manufacturers' specified operational and safety procedures. Employers should follow the manufacturer's operating procedures when training workers on the machines.

\section{Recommendation 4: Develop, implement, and enforce a comprehensive written hazardous energy control program including a lockout/tagout (LOTO) procedure and training for maintenance and servicing of bark blower trucks.}

Discussion: The employer's LOTO program was not comprehensive in that it did not specifically identify the LOTO process for the bark blower trucks. DOSH and OSHA require that employers establish procedures for isolating machines or equipment from the input of energy by affixing appropriate locks or tags to energy isolating devices. This is done to prevent any unexpected energization, start-up, or release of stored energy that would injure workers during servicing and maintenance of machines and equipment. LOTO procedures should be developed for each machine and address all forms of energy including electrical, hydraulic, pneumatic, and mechanical. A machine's LOTO procedure should outline the specific requirements and steps to properly perform LOTO on that machine, as well as address when LOTO should be implemented, such as while removing or breaking up jammed or tunneling material inside a blower truck hopper. For a hazardous energy control program to be effective, the employer must provide employees training and strictly enforce LOTO procedures. Enforcing a hazardous energy control program should include random inspections of employee work practices related to the required procedures.

In this case, the LOTO procedures should specifically include that when an employee has to enter the blower truck's hopper to clear a jam, to perform maintenance, or for any other reason that the blower system's engine must be lockout out by de-energizing, isolating, blocking and or dissipating all forms of hazardous energy. Then the employee entering the hopper must affix a lock to secure the energy isolating device. The incident bark blower truck's self-contained blower system was run by a diesel engine.Turning off the engine shuts down all power to the all the blower system's hydraulically controlled operations. Removing the key from the ignition creates a positive lockout of the PTO and hydraulic systems.

Recommendation 5: Develop, implement, and enforce a comprehensive written program detailing procedures for safe entry into or work in permit-required confined spaces, such as bark blower truck hoppers. 
Discussion: The employer did not consider the inside of the bark blower truck's hopper to be a permit-required confined space, so there was no training of employees on the OSHA requirements for a permit-required confined space. DOSH investigators determined that the inside of the cargo hopper was a permit-required confined space, in part due to the hazard of unguarded mechanical equipment, the auger system, and the feeder mechanism, operating within this space.

A confined space is -- according to the Washington State Chapter 296-809 Washington Administrative Code, Safety Standards for Confined Spaces - all of the following:

A. Large enough and arranged so an employee could fully enter the space and work.

B. Has limited or restticted entry of exit. Examples of spaces with limite or restricted entry are tanks, vessels, silos, storage bins, hoppers, vaults, excavations and pits.

C. Not primarily designed for human occupancy.

A permit-required confined space is a confined space that has one or more of the following characteristics capable of causing death or serious physical harm:

A. Contains or has a potential to contain a hazardous atmosphere.

B. Contains a material with the potential for engulfing someone who enters.

C. Has an internal configuration that could allow someone entering to be trapped or asphyxiated by inwardly converging walls or by a floor, which slopes downward and tapers to a smaller cross section.

D. Contains any physical hazard. This includes any recognized health or safety hazards including engulfment in solid or liquid material, electric shock, or moving parts.

E. Contains any other recognized serious safety or health hazard that could either:

i. Impair the ability to self-rescue; or

ii. Result in a situation that presents an immediate danger to life or health.

An overall permit-required confined space program should provide for:

A. Controlling and appropriately protecting employees from permit-required confined space hazards; and

B. Regulating employee entry into permit-required spaces.

A permit-required confined space entry program has several requirements which include, but are not limited to the following:

- Indentify all permit-required confined spaces in the workplace

- Inform employees and control entry to permit-required confined spaces 
- Implement measures to prevent unauthorized entry

- Develop a written permit required confined space program that describes the means, procedures, and practices to be used for safe entry into permit-required spaces

- Provide employee training, so that employees acquire the understanding, knowledge and skills necessary to safely perform assigned duties

- Implement procedures for entry permits that include an evaluation before employees enter of potential hazards from the permit-required confined space and the work to be performed

- Use an entry permit that contains all required information necessary to the entry operation

- Make sure entry supervisors perform their responsibilities and duties

- Make sure entrants know the hazardous conditions and their duties

For a complete list of requirements for Washington State employers written permitrequired confined space programs consult Chapter 296-809 WAC Safety Standards for Confined Spaces www.Ini.wa.gov/safety/rules/chapter/809/

For employers in federal OSHA jurisdiction, go to the OSHA website at: www.osha.gov/pls/oshaweb/owadisp.show document?p table=STANDARDS\&p id=97 $\underline{97}$

For further guidance, recommendations, and resouces please consult the reference section of this report.

Recommendation 6: Maintain machinery and equipment in safe operating condition. Remove malfunctioning machinery and equipment from service and repair or replace.

Discussion: Employers should remove machinery and equipment from service that has parts that become nonfunctional that could affect the safe operation of the equipment until they can be repaired. Employers should create a policy to ensure that machinery and equipment is regularly maintained and that they are promptly repaired or replaced so as to ensure worker safety.

The bark blower truck's broken hyrdraulic pressure sensors were a significant contributing factor in this incident. These sensors would detect if there was too much pressure from bulk material in the hopper on the auger system near the feeder. If there was too much pressure on the system then the conveyor belt would be shut off. The augers and stir rod would continue to rotate, driving material into the feeder until the pressure was lessened. This would prevent bulk material from jamming the blower 
system or tunneling above the conveyor belt. When the pressure was relieved on the auger system then the conveyor belt would start up again.

The incident bark blower truck was an older model, manufactured in 1998. The employer had unsuccessfully attempted to find pressures sensors to replace the ones that were inoperative. Recommendations made by company service mechanics to take the blower truck out of service because of this issue were not heeded. Due to the tunneling of bulk material in the hopper, caused in part by the broken sensors, the employer required their employees to be in the hopper to use a pitchfork to manually feed material into the feeder. After the fatal incident the employer had the truck removed and destroyed.

\section{Recommendation 7: Affix safety warning labels to equipment containing graphics providing hazard information and instructions for the safe use of equipment.}

Discussion: The incident bark blower truck did not have safety warning labels affixed to the hopper or any part of the truck warning of the hazards associated with use of the truck and its equipment components. Ensure that manufacturer provided warning labels are placed in locations on equipment as specified by the manufacturer. If the manufacturer has not provided warning labels, then aquire American National Standard (ANSI Z535.4) compliant warning labels from a distributor.

Research has shown that as a method of communicating safety information to workers equipment warning labels work best when combined with safety training and other forms of hazard communication.

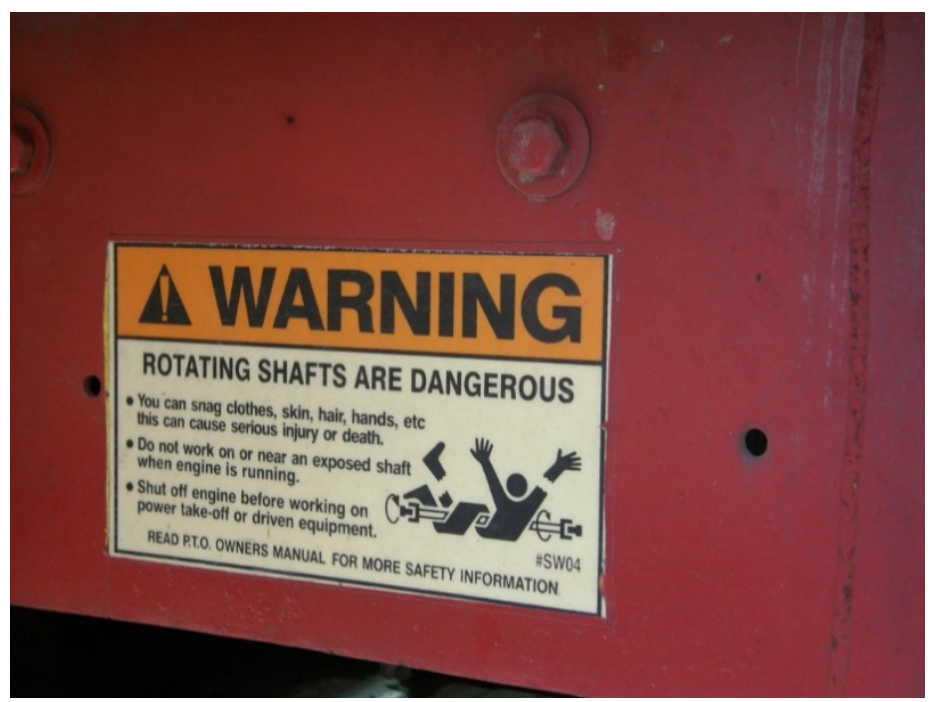

Photo 15: Safety warning label affixed to an employer owned bark blower truck (not the incident truck) warning of the hazard of rotating shafts. 


\section{Recommendation 8: Ensure that young workers and inexperienced workers are adequately trained and supervised to perform their jobs safely.}

Discussion: The 19-year-old victim died on his second day of what was to be a summer job. His work experience was limited to a previous job at a hardware store. He had no experience working in the landscaping industry, nor had he previously worked with a bark blower truck or any other large mechanized equipment. Formal safety training was not provided by the employer. He had received informal verbal instruction from a supervisor on the previous work day. New employees were generally assigned the task of working in the hopper of the bark blower truck because other employees did not want to it. There was a high turnover of mostly young employees who worked on the bark blower truck crews, so there was relatively little individual or collective experience among either the supervisors or laborers.

According to the Centers for Disease Control and Prevention (CDC), young workers aged 15 - 24 years face high risk for injury while on the job. Other research has shown that workers new to a job or task, or facing a new hazard regardless of their age have much higher injury rates than more experienced workers.

Young workers because of their age, work inexperience, and their desire to impress their employer by showing eagerness in carrying out their assigned work tasks, may not recognize or be willing to report dangerous conditions or hazards in the workplace. They may also be less likely to speak up to someone in a postion of authority, such as a supervisor or company owner. Considering these factors employers should ensure that young and inexperienced workers are not assigned to hazardous tasks. Additionally, employers should provide effective orientation and increased supervision to young and inexperienced workers. They should be encouraged to ask questions and ask for assistance. Training should take into account their lack of work experience. The training should be specific to the workplace and job duties and it should be ongoing. [Miller, et al]

Young workers should know their rights, which include the right to a safe and healthy workplace and the right to refuse dangerous work. (See the L\&I website for information on workplace rights at: www.Ini.wa.gov/workplacerights/)

\section{REFERENCES}

Accident Prevention Program. Washington State Department of Labor and Industries. http://www.Ini.wa.gov/safety/topics/atoz/APP/Default.asp

American National Standards Institute (ANSI). Safety signs and labels (Standard No. ANSI Z535.4-2011). New York, NY, USA: ANSI; 2011. https://webstore.ansi.org/RecordDetail.aspx?sku=ANSI\%2fNEMA+Z535.4-2011 
American Society of Safety Engineers. ANSI/ASSE Z244.1 - 2016, The Hazardous Control of Energy, Lockout, Tagout and Alternative Methods.

http://www.asse.org/ansi/asse-z244-1-2016-the-control-of-hazardous-energy-lockouttagout-and-alternative-methods/

Breslin FC, Smith P. Trial by fire: A multivariate examination of the relation between job tenure and work injuries. Occupational and Environmental Medicine, 2006;63:27-32. http://oem.bmj.com/content/63/1/27.abstract?sid=ee2fdad4-00a6-4ee4-b76c$\underline{\mathrm{f} 12 \mathrm{~b} 2623 \mathrm{f} 710}$

Canadian Centre for Occupational Health and Safety. New Worker Safety Infographic. http://images.ccohs.ca/products/infographics/download/newWorkers.jpg

Institute for Work \& Health. "Newness" and the risk of occupational injury. Issue briefing. https://www.iwh.on.ca/system/files/documents/iwh briefing newness 2009.pdf

McGrath, John M. (2011) The Role of Equipment Warning Labels in the Industrial Workplace, International Journal of Occupational Safety and Ergonomics, 17:1, 49-60. http://dx.doi.org/10.1080/10803548.2011.11076871

Miller ME, Handleman E, Lewis C. Protecting young workers: Coordinated strategies help to raise safety awareness. Professional Safety, June 2007.

Morassaei S, Breslin FC, Shen M, Smith PM. Examining job tenure and lost-time claim rates in Ontario, Canada, over a 10-year period, 1999-2008. Occupational and Environmental Medicine, 2013;70:171-178. http://oem.bmj.com/content/70/3/171

National Institute for Safety and Health (NIOSH). Young Worker Health and Safety (resoures and research). https://www.cdc.gov/niosh/topics/youth/default.html

$\mathrm{NIOSH}$, Fatality Assessment and Control Evaluation (FACE) Program. Fifteen-Year-Old Hispanic Youth Dies After Entering the Hopper of a Bark Blower - Maryland. NIOSH inhouse FACE report: 2004-08. http://www.cdc.gov/niosh/face//n-house/full200408.html

$\mathrm{NIOSH}$, Fatality Assessment and Control Evaluation (FACE) Program. Landscaper Dies Inside the Hopper of a Truck Mounted Pneumatic Blower - Massachusetts.

Massachusetts FACE case report: 05-MA-074.

http://www.cdc.gov/niosh/face/stateface/ma/05ma074.html

OSHA. Confined Spaces. (rules and guidance)

https://www.osha.gov/SLTC/confinedspaces/

OSHA. Control of Hazardous Energy. (rules and guidance).

https://www.osha.gov/SLTC/controlhazardousenergy/

Peterson Pacific Corp. http://www.petersoncorp.com/blower-truckpedia/

Remembering Bradley Hogue on Worker Memorial Day. https://www.youtube.com/watch?v=O8ihwJt7XmQ

Washington State Department of Labor and Industries. Confined Space (rules and guidance) http://www.Ini.wa.gov/safety/topics/atoz/topic.asp?KWID=65 
Washington State Department of Labor and Industries. Lockout/Tagout (LOTO) Control of Hazardous Energy, Interlock Devices. (rules and guidance) http://www.Ini.wa.gov/Safety/Topics/AToZ/LOTO/Default.asp

Weather Underground.

http://www.wunderground.com/history/airport/KPAE/2014/7/7/DailyHistory.html?req city =Duvall\&req state $=$ WA\&req statename $=\&$ reqdb.zip $=98019 \&$ reqdb. magic $=1 \&$ reqdb. $\mathrm{wm}$ o=99999

WorkSafe BC. Resources for Young Workers. http://www2.worksafebc.com/Topics/YoungWorker/Resources-Employers.asp WorkSafe BC. Young and New Worker Programs. A series of videos. http://www2.worksafebc.com/Publications/Multimedia/Videos.asp?ReportlD=34880

\section{INVESTIGATOR INFORMATION}

Todd Schoonover has a $\mathrm{PhD}$ in Industrial Hygiene from the University of Illinois at Chicago. He is a Certified Industrial Hygienist $(\mathrm{ClH})$ and Certified Safety Professional (CSP). Todd is currently the Principle Investigator for the WA FACE Program.

Christina Rappin has a BAS from The Evergreen State College. She is a Research Investigator with the WA FACE program.

Randy Clark has a BA from the Evergreen State College. He is a Safety and Health Specialist with the WA FACE Program.

\section{WASHINGTON STATE FACE PROGRAM INFORMATION}

The Washington State Fatality Assessment and Control (WA FACE) program is one of many workplace health and safety programs administered by the Washington State Department of Labor \& Industries' Safety \& Health \& Research for Prevention (SHARP) program. It is a research program designed to identify and study fatal occupational injuries. Under a cooperative agreement with the National Institute for Occupational Safety and Health (NIOSH grant\# 5 U60OH008487), WA FACE collects information on occupational fatalities in WA State and targets specific types of fatalities for evaluation. WA FACE investigators evaluate information from multiple sources. Findings are summarized in narrative reports that include recommendations for preventing similar events in the future. These recommendations are distributed to employers, workers, and other organizations interested in promoting workplace safety. NIOSH-funded, statebased FACE programs include: California, Kentucky, Massachusetts, Michigan, New York, Oregon, and Washington. WA FACE does not determine fault or legal liability associated with a fatal incident. Names of employers, victims and/or witnesses are not 
included in written investigative reports or other databases to protect the confidentiality of those who voluntarily participate in the program.

Additional information regarding the WA FACE program can be obtained from:

Washington State FACE Program

www.Ini.wa.gov/Safety/Research/FACE/default.asp

PO Box 44330

Olympia, WA 98504-4330

$1-888-667-4277$

\section{ACKNOWLEDGMENTS}

This report was reviewed by stakeholders from labor and business communities and various Washington State and Federal worker safety agencies. Though we are unable to acknowledge specific individuals for their contributions to this report, we would like to recognize the following for their help and support of the FACE mission and objectives:

- Division of Occupational Safety and Health (DOSH)

- Federal FACE Program management (NIOSH)

- Safety \& Health Assessment \& Research for Prevention (SHARP) 